\title{
Effect of Nanoalumina on Sex Hormones and Fetuses in Pregnant Rats
}

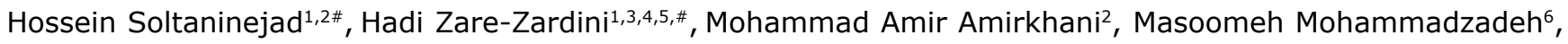
Akram Ghadiri-Anari ${ }^{7}$, Mahtab Ordouei ${ }^{3,8}$, Ashraf Alemi ${ }^{9}$, Adel Ghorani-Azam ${ }^{10}$

${ }^{1}$ Department of Nanobiotechnology, Faculty of Biological Sciences, Tarbiat Modares University, Tehran, Iran

${ }^{2}$ Stem Cell and Regenerative Medicine Institute, Tehran University of Medical Sciences, Tehran, Iran

${ }^{3}$ Hematology and Oncology Research Center, Shahid Sadoughi University of Medical Sciences, Yazd, Iran

${ }^{4}$ Department of Sciences, Farhangian University, Isfahan, Iran

${ }^{5}$ Medical Nanotechnology and Tissue Engineering Research Center, Yazd Reproductive Sciences Institute, Shahid Sadoughi University of Medical Sciences, Yazd, Iran

${ }^{6}$ Research and Clinical Center for Infertility, Shahid Sadoughi University of Medical Sciences, Yazd, Iran

${ }^{7}$ Department of Internal Medicine, Diabetes Research Center, Shahid Sadoughi University of Medical Sciences, Yazd, Iran

${ }^{8}$ Department of Pediatrics, Shahid Sadoughi University of Medical Sciences, Yazd, Iran

${ }^{9}$ Department of Biochemistry, Abadan Faculty of Medical Sciences, Abadan, Iran

${ }^{10}$ Department of Forensic Medicine and Toxicology, School of Medicine, Urmia University of Medical Sciences, Urmia, Iran

"Co-first author

\section{ABSTRACT}

Objective: This study aimed at investigating the effect of nanoalumina on sex hormones, and fetuses in pregnant rats.

Methods: In this study, sixty-four pregnant rats were divided into eight groups. The control and the injectioncontrol group received normal food and water, and $0.5 \mathrm{ml}$ of distilled water, respectively. Treatment groups were treated with $25,50,100,250,500$, and $1000 \mu \mathrm{g} / \mathrm{ml}$ concentrations of Nanoalumina from the $7^{\text {th }}$ day until the 18th day of pregnancy. On the $18^{\text {th }}$ day, the rats were investigated in terms of their hormone levels. We evaluated the number of healthy and aborted offspring, as well as fetus size.

Results: Nanoalumina caused an increase in progesterone hormones at the concentrations of 250, and $500 \mu \mathrm{g} / \mathrm{ml}$, and a significant reduction in estrogen hormone and aborted fetuses at the concentrations of 250 and $500 \mu \mathrm{g} /$ $\mathrm{ml}(p<0.05)$. The largest and smallest size of fetuses were observed in $500 \mu \mathrm{g} / \mathrm{ml}$ and $1000 \mu \mathrm{g} / \mathrm{ml}$, respectively. The highest number of aborted fetuses was observed in the group treated with the $500 \mu \mathrm{g} / \mathrm{ml}$ concentration. There was no aborted fetuses with $25,50,100$, control, and injectioncontrol groups.

Conclusions: Due to nanoalumina toxicity, it must be used with caution.

Keywords: nanoalumina, fetuses, sex hormones, size, toxicity

\section{INTRODUCTION}

Recently, nanostructures have found increased applications in technology, research and medicine (Liang et al., 2012; Bellah et al., 2012). These compounds have unique properties because of their small size. In the past decades, nanotechnology has been increasingly used in sciences due to their wide range of biomedical applications, for example in coating, drug delivery, medical imaging, and etc. (Latysh et al., 2006; Boncel et al., 2012; He et al., 2010; Amiri et al., 2012; Zardini et al., 2012; 2014). In addition to its beneficial properties, nanostructures have dangerous toxicity, especially on humans (Zare-Zardini et al., 2015a; b). For some types of particles, the smaller they are, the greater their surface area to volume ratio and the higher their chemical reactivity and biological activity (Leslie-Pelecky \& Rieke, 1996; Hahn, 2003). The toxicity of different nanostructures has been proven on different organs, such as blood, lungs, liver, skin, gut, and etc (Faqi et al., 2008). Once in the blood stream, nanostructures can be transported around the body and be taken up by organs and tissues, including the brain, heart, liver, kidneys, spleen, bone marrow and nervous system (Tseng et al., 2008).

Nanomaterials are toxic for human tissues and in cell-cultures, resulting in increased oxidative stress, inflammatory cytokine production and cell death. Nanostructures may be taken up by cell mitochondria in the cell nucleus. Nanomaterials can cause DNA mutation and induce major structural damage to the mitochondria. One organ affected by nanostructures is the sexual organ. Here, it is important that nanostructures can penetrate deeper into skin layers and possibly be absorbed into the systemic circulation and build up in tissues, especially in sexual organs. Alumina is one of the inert biomaterials used in biomedicine (El-S'adany et al., 2013; Affatato et al., 2012). This nanostructure has been defined as a suitable compound to be used in different fields of life.

The aim of the present study was to prepare nanoalumina by the sol-gel method and investigate its toxicity on changes of sex hormone and abortion in pregnant rats.

\section{MATERIALS AND METHODS}

According to our previous study (Mehregan et al., 2015), we used the sol-gel method to synthesize the nanostructures; and we used X-Ray Diffraction (XRD) and transmission electron microscope (TEM) to identify the crystalline mineralogical phases of the powders and the micrographs, respectively. We randomly divided eighty female rats into 8 groups, including six treatment groups, one control group, and one injection control group. Since the formation of a vaginal plug (G0), pregnant female rats were maintained in vitro for 7 days. Different concentrations of nanostructures $(25,50,100,250,500$, and 
$1000 \mu \mathrm{g} / \mathrm{ml}$ ) were intraperitoneally injected every day from the seventh day of pregnancy until the eighteenth day. Table 1 depicts the summarized information from the 8 groups.

On the $18^{\text {th }}$ day of pregnancy, we assessed the rats' hormone levels, the number of healthy embryos, and aborted fetuses. After the injection, we took blood samples from the rats' hearts every other day up to the $18^{\text {th }}$ day of pregnancy. Using biochemical tests, we compared the rats considering their levels of estrogen and progesterone hormones. Other variables investigated include the number of healthy embryos and the number of aborted fetuses.

\section{RESULTS}

We used the sol-gel method to synthesize alumina nanoparticles. The resulting nanoalumina powders were characterized by X-ray diffraction and scanning electron microscopy (TEM). Figure 1 shows the XRD pattern of alumina powder. The peak broadening at lower angle in Figure 1 is more meaningful for the calculation of particle size; therefore we calculated the size of the nanocrystals with the Debye-Scherrer formula, using reflection from the XRD pattern. Figure 2 shows the transmission electron microscopy (TEM) micrographs from the alumina powder obtained from the aluminum chloride solution $(0.1 \mathrm{M})$, heat-treated at $100^{\circ} \mathrm{C}$ for 24 hours. There are two types of particles with different geometries, namely: needle-shaped particles with average particle size below $30 \mathrm{~nm}$ and spherical particles, with average size below $20 \mathrm{~nm}$.

Among six treatment groups, the highest level of progesterone hormone was in the group treated with the $\mathrm{Al}_{2} \mathrm{O}_{3}$ nanostructure at a concentration higher than $500 \mu \mathrm{g} / \mathrm{ml}$ $(25150 \pm 3855 \mathrm{pg} / \mathrm{ml} / 24)$. The lowest level of progesterone hormone was seen in the control group in comparison with six treatment groups and the injection control group $(7800 \pm 812 \mathrm{pg} / \mathrm{ml}$ ) (Figure 3 ). According to our results, there were significant differences among the groups $(p<0.05)$. The hormone raise was consistent with the increase in nanostructure concentration, up to $500 \mu \mathrm{g} / \mathrm{ml}$ $(p<0.05)$. At $1000 \mu \mathrm{g} / \mathrm{ml}$, the level of progesterone hormone was decreased. Estrogen among the treated groups was highest in the group treated with 250 and $500 \mu \mathrm{g} / \mathrm{ml}$ $(69850$ and $68750 \mathrm{pg} / \mathrm{ml}$ in 250 and $500 \mu \mathrm{g} / \mathrm{ml}$, respectively). The injection control group had the highest estrogen level $(75400 \pm 3723 \mathrm{pg} / \mathrm{ml}$ ) (Figure 4). There was no significant difference involving the group treated with the concentration of 250 and $500 \mu \mathrm{g} / \mathrm{ml}$. The difference between the control group and the injection-control group, 250 and 500 ppm groups was significant, regarding reduction in estrogen hormone level $(p<0.001)$. The difference between the $1000 \mu \mathrm{g} / \mathrm{ml}$ group and the injection control group, the 250 and $500 \mu \mathrm{g} / \mathrm{ml}$ groups, and the control group was significant regarding reduction in estrogen hormone level $(p<0.05)$.

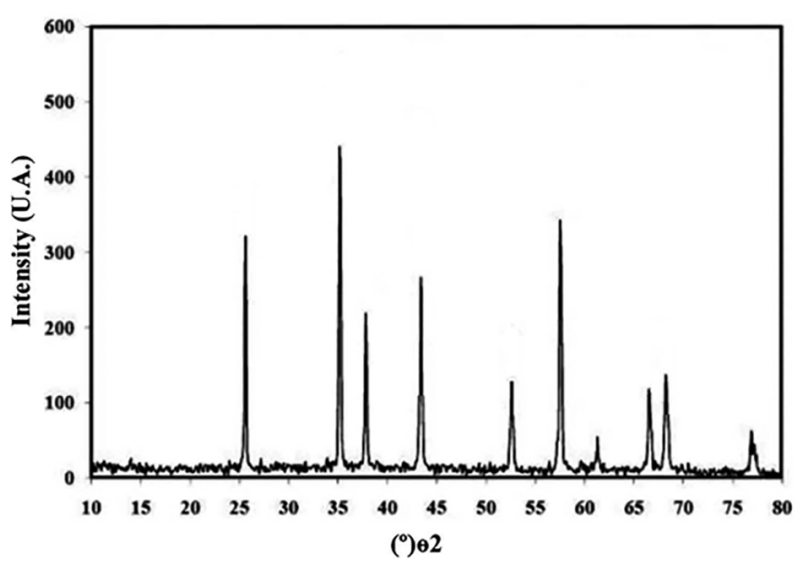

Figure 1. The XRD image nanoalumina.

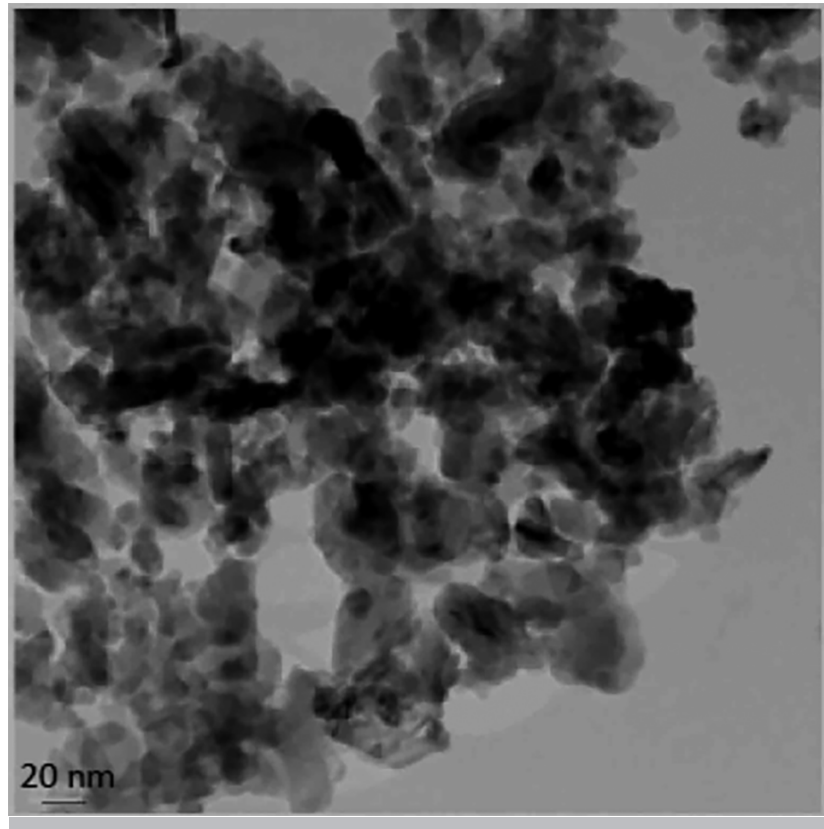

Figure 2. TEM image of nanoalumina.

In higher concentrations of nanostructures $(1000 \mu \mathrm{g} /$ $\mathrm{ml}$ ), the reduction of two hormones was lower than in other treated groups. The results showed that the number of healthy embryos was highest at 25, 50 and $1000 \mu \mathrm{g} / \mathrm{ml}$ concentrations in comparison with other concentrations, e.g. 100,250 and $500 \mu \mathrm{g} / \mathrm{ml}$. The number of healthy em-

Table 1. Details from the 8 groups in this study that were treated with different concentrations of nanoalumina.

\begin{tabular}{|l|l|}
\hline \hline Groups & \\
\hline Control & Normal condition, water, regular food \\
\hline Injection Control & Injection of distilled water \\
\hline Treatment group 1 & Injection of $0.5 \mathrm{ml}$ nanopowder $(25 \mu \mathrm{g} / \mathrm{ml})$ \\
\hline Treatment group 2 & Injection of $0.5 \mathrm{ml}$ nanopowder $(50 \mu \mathrm{g} / \mathrm{ml})$ \\
\hline Treatment group 3 & Injection of $0.5 \mathrm{ml}$ nanopowder $(100 \mu \mathrm{g} / \mathrm{ml})$ \\
\hline Treatment group 4 & Injection of $0.5 \mathrm{ml}$ nanopowder $(250 \mu \mathrm{g} / \mathrm{ml})$ \\
\hline Treatment group 5 & Injection of $0.5 \mathrm{ml}$ nanopowder $(500 \mu \mathrm{g} / \mathrm{ml})$ \\
\hline Treatment group 6 & Injection of $0.5 \mathrm{ml}$ nanopowder $(1000 \mu \mathrm{g} / \mathrm{ml})$ \\
\hline
\end{tabular}




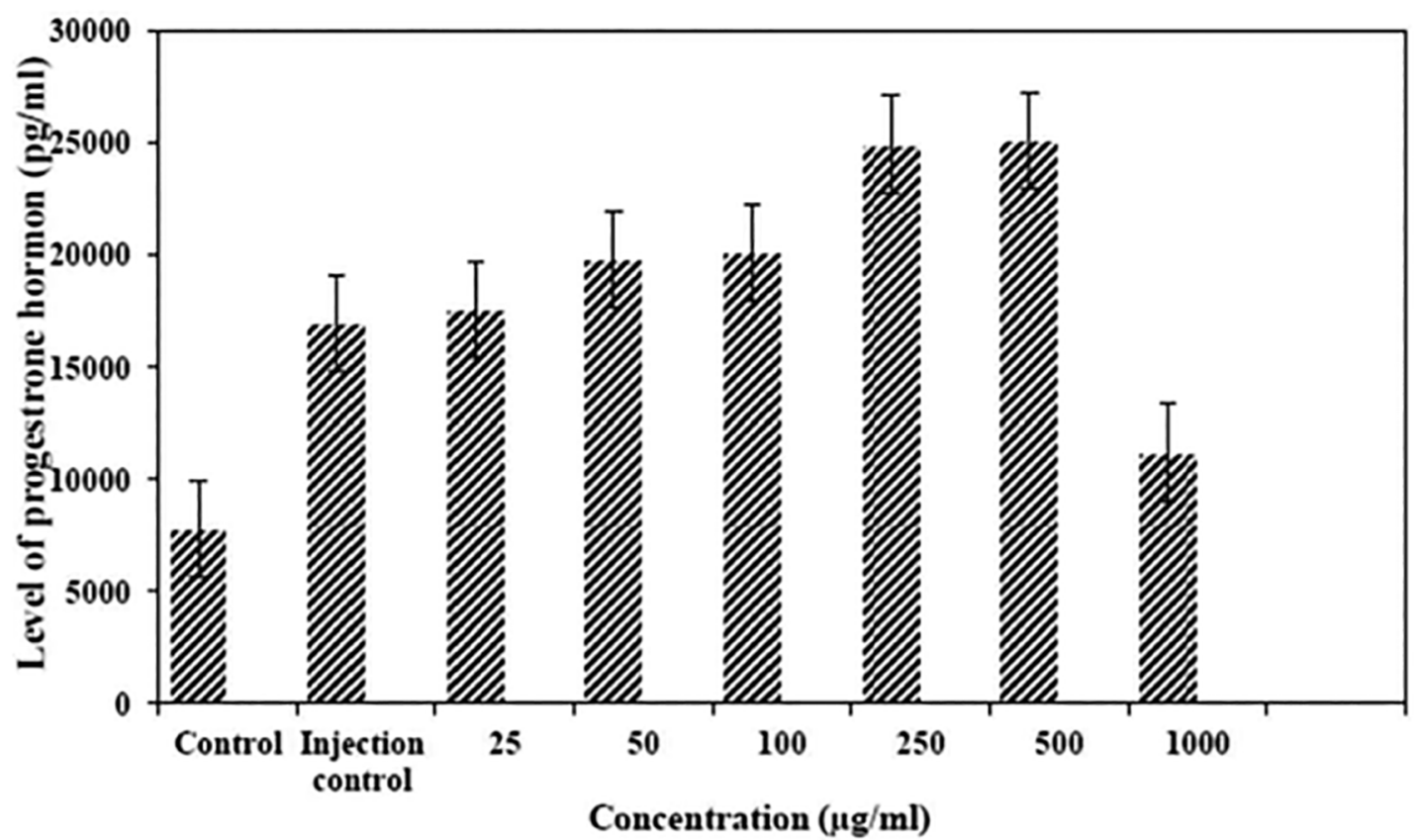

Figure 3. Comparison of progesterone levels among the eight groups.

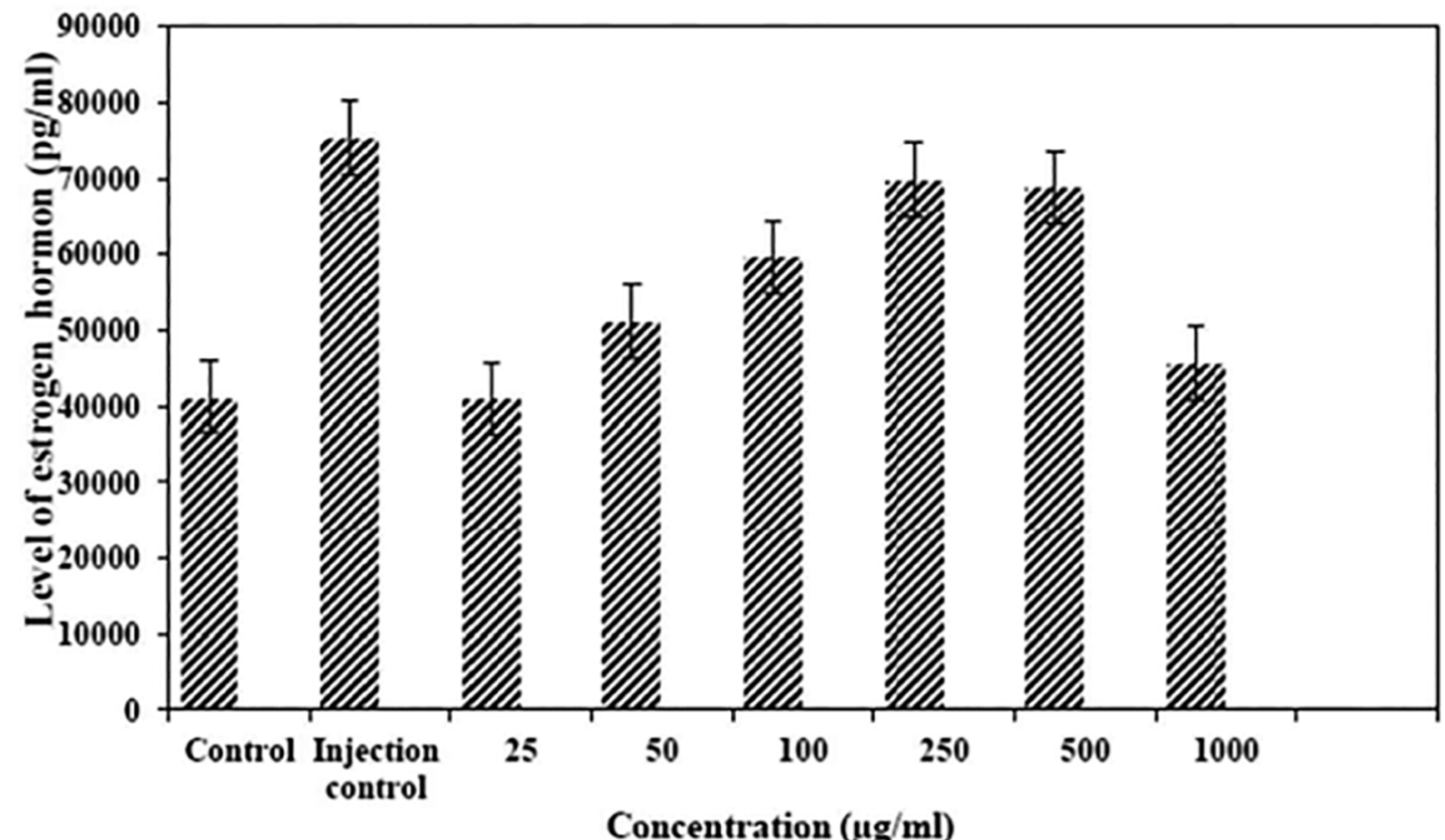

Figure 4. Comparison of estrogen levels among the eight groups.

bryos was 15 and 14 in control group and in the injection control group, respectively (Table 2 ). There were no significant differences among the groups regarding the number of healthy embryos.

As shown in this table, all the groups were different regarding the number of aborted fetuses. The highest number of aborted fetuses was in the group treated at $500 \mu \mathrm{g} / \mathrm{ml}$ concentration (12 aborted fetuses). There were no aborted fetuses in the $25,50,100$, and in the control groups. There were no aborted fetuses in the injection control group. There was a significant difference among the groups regarding the mean number of aborted fetuses. The difference between the control and the injection control group as well as the 100, 250 and $500 \mu \mathrm{g} / \mathrm{ml}$ and the injection control group was significant regarding the mean value of aborted fetuses $(p<0.05)$. The difference between the $1000 \mu \mathrm{g} / \mathrm{ml}$ and the injection control group, 150,250 and $500 \mu \mathrm{g} / \mathrm{ml}$ groups was significant regarding the mean number of aborted fetuses $(p<0.05)$. 
Table 2. Results from the number of healthy and aborted fetuses in eight groups.

\begin{tabular}{|l|c|c|}
\hline \hline Groups & Healthy Fetus & Aborted Fetus \\
\hline Control & 15 & 0 \\
\hline Injection Control & 14 & 0 \\
\hline Nanoalumina $(25 \mu \mathrm{g} / \mathrm{ml})$ & 15 & 0 \\
\hline Nanoalumina $(50 \mu \mathrm{g} / \mathrm{ml})$ & 14 & 0 \\
\hline Nanoalumina $(100 \mu \mathrm{g} / \mathrm{ml})$ & 15 & 2 \\
\hline Nanoalumina $(250 \mu \mathrm{g} / \mathrm{ml})$ & 10 & 12 \\
\hline Nanoalumina $(500 \mu \mathrm{g} / \mathrm{ml})$ & 8 & 3 \\
\hline Nanoalumina $(1000 \mu \mathrm{g} / \mathrm{ml})$ & 13 & \\
\hline
\end{tabular}

According to acquired data, the largest and smallest sizes of fetuses were seen in the $500 \mu \mathrm{g} / \mathrm{ml}$ and the $1000 \mu \mathrm{g} /$ $\mathrm{ml}$ of nanostructures, respectively. Between all groups, the smallest size belonged to the control group. The reduction in fetus size was significant between the control and the injection control groups, 100,250 and $500 \mu \mathrm{g} / \mathrm{ml}$ groups $(p<0.05)$. The increase of size was significant between the 500 and $1000 \mu \mathrm{g} / \mathrm{ml}$ groups $(p<0.05)$ (Figure 5$)$.

\section{DISCUSSION}

Nanomaterials have toxicological properties in comparison to the same substance in the bulk form (Zhang et al., 2014). The use and release of nanostructures into the environment can have effects on each stage of the life cycle (Palombo et al., 2014). The toxicity is a function of particle number and surface area, rather than mass. The knowledge about the toxicity of nanomaterials is incomprehensible, especially long-term environmental impacts and chronic health impacts (Sharifi et al., 2012). These nanomaterials can cause defects on all organs of the body such as liver, blood, brain, lung and etc. (Kermanizadeh et al., 2015; Kumar et al., 2014; Zhao \& Castranova, 2011; Soleymani et al., 2014). In this study, we investigated the effects of nanoalumina on changes in estrogen and progesterone levels, the total size of the fetus and abortion. We assessed the effects of different concentrations of nanoalumina on progesterone, and it showed changes in hormone levels compared to the control group in a way that treatment with concentration of $500 \mu \mathrm{g} / \mathrm{ml}$ led to the highest amount of change in progesterone and other concentrations, which decreased the levels of progesterone. Considering both treatment and control groups, the lowest level of progesterone was in the control group.

The increase found in the group treated with concentration of 250 and $500 \mu \mathrm{g} / \mathrm{ml}$ was statistically significant $(p<0.05)$ in comparison with all other groups. According to the acquired data, we can conclude that these examined concentrations have the ability to cause changes in hormone levels and these changes were more obvious among the 250 and $500 \mu \mathrm{g} / \mathrm{ml}$ concentrations. This suggests that increases in concentrations can affect hormone levels only up to a certain extent. Considering changes in the estrogen level after being treated with six concentrations of nanoalumina, we noticed that nanoalumina change estrogen hormone levels in a way that lower concentrations (25, $50,150,300$ and $500 \mu \mathrm{g} / \mathrm{ml}$ ) increase estrogen and higher concentrations $(1000 \mu \mathrm{g} / \mathrm{ml})$ decreased estrogen levels in comparison with the control group. The decline in the level of estrogen in the control groups was significant compared to the three other groups treated with 100, 250 and $500 \mu \mathrm{g} / \mathrm{ml}$ concentrations of nanoalumina $(p<0.002)$.

The lowest estrogen level was in the group treated with nanoalumina at $1000 \mu \mathrm{g} / \mathrm{ml}$ concentration in comparison with five other treatment groups, and this different was statistically significant $(p<0.05)$. Therefore, we may suppose that the increase in nanoalumina concentration from $500 \mu \mathrm{g} / \mathrm{ml}$ to $1000 \mu \mathrm{g} / \mathrm{ml}$ can reduce estrogen level. According to the results obtained, we could say that nanoalumina may increase estrogen levels only up to certain concentrations when compared to the control group, and in higher concentrations it reduces the estrogen level. Given that recent studies proved that silver nanoparticles can have different effects on various body parts of living organisms, we can suppose that the level of these nanostructures bring about changes to estrogen levels; however, the exact mechanism has not been examined yet. Regarding the number of healthy embryos after treatment with nanoalumina, there were changes in each group.

Nanoalumina reduced the number of healthy embryos in a way that the number of healthy embryos was 8 at the concentration $500 \mu \mathrm{g} / \mathrm{ml}$. The difference between 500 and $1000 \mu \mathrm{g} / \mathrm{ml}$ was not significant $(p>0.05)$ (Figure $3)$. Overall, we can conclude that high concentrations of nanoalumina $(500 \mu \mathrm{g} / \mathrm{ml})$ have a significant effect on reducing the number of healthy embryos. Considering this data and other reports, the use of nanostructures must bear more caution. Hormonal levels changes in pregnant females can affect menstrual function, fertility, and fetus health (Scsukova et al., 2015). Similar studies showed that nanoparticles change the hypothalamic-pituitary-ovarian axis function and cause female infertility. The buildup of these nanoparticles can also cause abortion. Size, exposure time and concentration have significant effects on the severity of side effects. We obtained similar results in our study (Rollerova et al., 2015; Oberdörster et al., 2004; Liu et al., 2016; Kong et al., 2016). We also showed a significant and concentration-dependent effect of nanoalumina on changes in sex hormones.

As mentioned above, hormonal changes in the treatment groups were more severe than in the control groups; although these changes were also seen among the injection control group. Therefore, considering the effective changes in the injection control group, the significant effects of nanoalumina injection on sex hormones does not seem to be justified. But the big difference between the nano-treated groups compared to the injection control and control groups is the number of aborted fetuses, which is very significant in the 500 and $1000 \mu \mathrm{g} / \mathrm{ml}$ of nanoalumina. Therefore, due to the effective hormonal changes in the injection control group, it may not be possible to justify the hormonal changes caused by the nanoalumina injection; however, the high level of abortion in the nano-treated groups can prove the risk of high doses of this nanoparticle. Yang et al. (2018) showed that gold nanoparticles can induce abortion by inhibiting ectodermal differentiation. This group indicted that treatment with gold nanoparticles during 


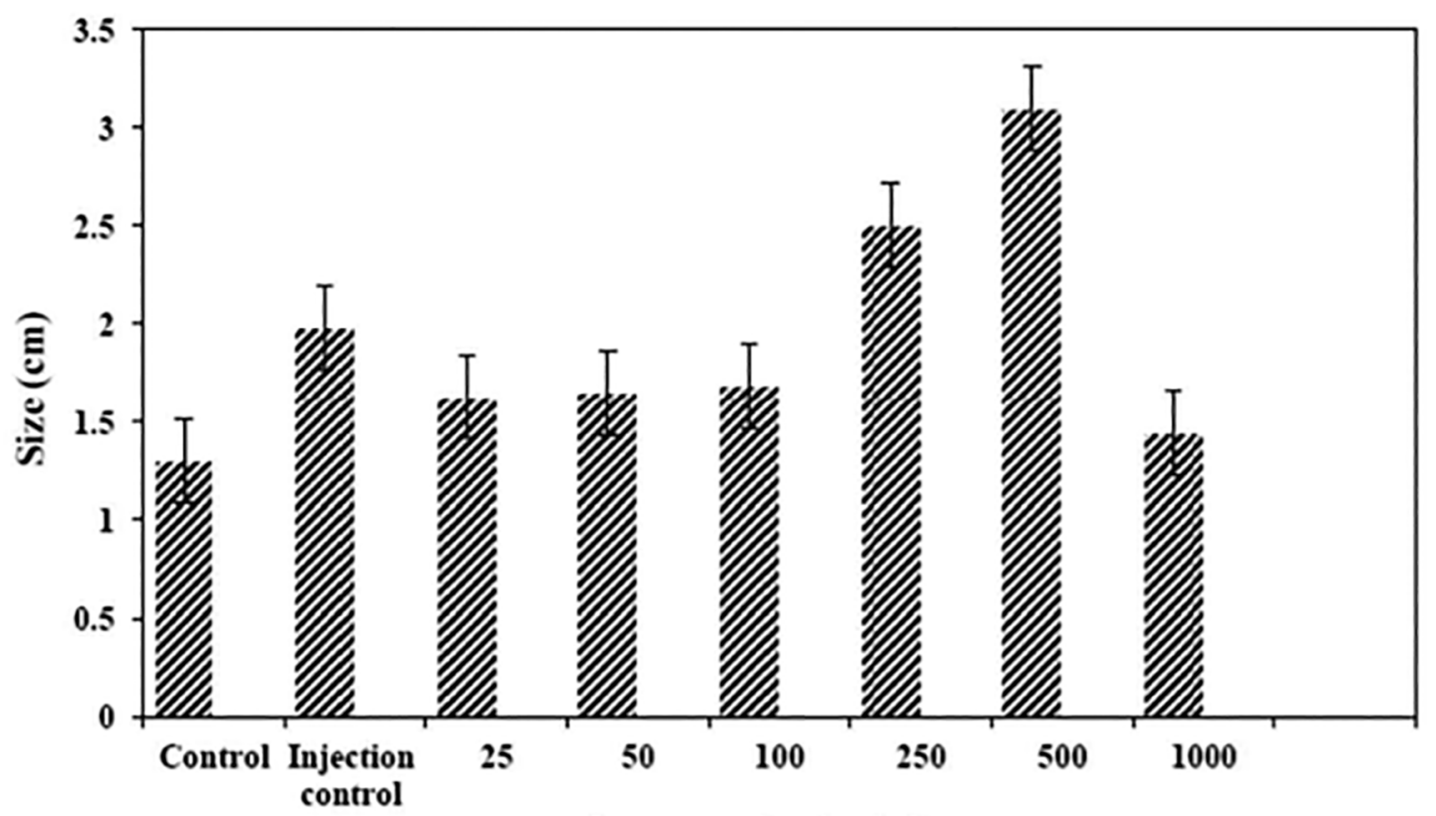

Concentration $(\mu \mathrm{g} / \mathrm{ml})$

Figure 5. Comparison of average total size of fetuses among the eight groups.

early pregnancy causes significant increases in the rate of abortions and stillbirths (Yang et al., 2018). Similar results showed that sex hormone imbalances can increase the risk of spontaneous abortion in pregnant rats (Li et al., 2013). We showed similar data in our study.

Therefore, according to the results of our study on the significant effect of different concentrations of nanoalumina on sex hormones and in particular - increasing the number of abortions, the use of this nanoparticles, especially in high doses in different products, should be more cautious.

\section{CONFLICT OF INTEREST}

All authors declare that they have no conflicts of interest.

\section{Corresponding author:}

Hadi Zare-Zardini

-Hematology and Oncology Research Center

Shahid Sadoughi University of Medical Sciences

Yazd, Iran.

-Department of Sciences

Farhangian University

Isfahan, Iran

- Medical Nanotechnology and Tissue Engineering Research Center

Yazd Reproductive Sciences Institute

Shahid Sadoughi University of Medical Sciences

Yazd, Iran.

E-mail: hadizarezardini@gmail.com

\section{REFERENCES}

Affatato S, Taddei P, Carmignato S, Modena E, Toni A. Severe damage of alumina-on-alumina hip implants: Wear assessments at a microscopic level. J Eur Ceram Soc. 2012;32:3647-57. DOI: 10.1016/j.jeurceramsoc. 2012.05.023
Amiri A, Zardini HZ, Shanbedi M, Maghrebi M, Baniadam $M$, Tolueinia B. Efficient method for functionalization of carbon nanotubes by lysine and improved antimicrobial activity and water-dispersion. Mater Lett. 2012;72:153-6. DOI: 10.1016/j.matlet.2011.12.114

Bellah MM, Christensen SM, Iqbal SM. Nanostructures for Medical Diagnostics. J Nanomater. 2012;2012:21. DOI: $10.1155 / 2012 / 486301$

Boncel S, Herman AP, Walczak KZ. Magnetic carbon nanostructures in medicine. J Mater Chem. 2012;22:31-7. DOI: 10.1039/C1JM13734D

El-S'adany AF, Masoud GE, Kamel MS, Korsel AM. Fracture resistance of all ceramic crowns supported by zirconia and alumina versus titanium implant abutments. Tanta Dent J. 2013;10:103-11. DOI: 10.1016/j.tdj.2013.11.001

Faqi AS, Richards D, Hauswirth JW, Schroeder R. Maternal and developmental toxicity study of sodium azide in rats. Regul Toxicol Pharmacol. 2008;52:158-62. PMID: 18755233 DOI: $10.1016 /$ j.yrtph.2008.08.001

Hahn H. Unique Features and Properties of Nanostructured Materials. Adv Eng Mater. 2003;5:277-84. DOI: 10.1002/ adem. 200310091

He J, Qi X, Miao Y, Wu HL, He N, Zhu JJ. Application of smart nanostructures in medicine. Nanomedicine. 2010;5:112938. PMID: 20874025 DOI: $10.2217 / \mathrm{nnm} .10 .81$

Kermanizadeh A, Balharry D, Wallin H, Loft S, Møller P. Nanomaterial translocation--the biokinetics, tissue accumulation, toxicity and fate of materials in secondary organs--a review. Crit Rev Toxicol. 2015;45:837-72. PMID: 26140391 DOI: 10.3109/10408444.2015.1058747 
Kong L, Gao X, Zhu J, Cheng K, Tang M. Mechanisms involved in reproductive toxicity caused by nickel nanoparticle in female rats. Environ Toxicol. 2016;31:1674-83. PMID: 27257140 DOI: $10.1002 /$ tox. 22288

Kumar A, Kumar P, Anandan A, Fernandes TF, Ayoko GA, Biskos G. Engineered Nanomaterials: Knowledge Gaps in Fate, Exposure, Toxicity, and Future Directions. J Nanomater. $2014 ; 2014: 16$. DOI: $10.1155 / 2014 / 130198$

Latysh V, Krallics G, Alexandrov I, Fodor A. Application of bulk nanostructured materials in medicine. Curr Appl Phys. 2006;6:262-6. DOI: 10.1016/j.cap.2005.07.053

Leslie-Pelecky DL, Rieke RD. Magnetic Properties of Nanostructured Materials. Chem Mater. 1996;8:1770-83. DOI: $10.1021 / \mathrm{cm} 960077 \mathrm{f}$

Li C, Li X, Suzuki AK, Zhang $Y$, Fujitani $Y$, Nagaoka $K$, Watanabe G, Taya K. Effects of exposure to nanoparticle-rich diesel exhaust on pregnancy in rats. J Reprod Dev. 2013;59:145-50. PMID: 23257834 DOI: 10.1262/ jrd.2012-145

Liang XJ, Kumar A, Shi D, Cui D. Nanostructures for Medicine and Pharmaceuticals. J Nanomater. 2012;2012:921897. DOI: $10.1155 / 2012 / 921897$

Liu XQ, Zhang HF, Zhang WD, Zhang PF, Hao YN, Song $\mathrm{R}$, Li L, Feng YN, Hao ZH, Shen W, Min LJ, Yang HD, Zhao $Y$. Regulation of neuroendocrine cells and neuron factors in the ovary by zinc oxide nanoparticles. Toxicol Lett. 2016;256:19-32. PMID: 27215404 DOI: 10.1016/j. toxlet.2016.05.007

Mehregan M, Soltaninejad $\mathrm{H}$, Toluei Nia B, Zare-Zardini $\mathrm{H}_{\text {, }}$ Zare-Shehneh M, Ebrahimi L. Al2O3 Nanopowders, a Suitable Compound for Active Control of Biofouling. J Nano Res 2015;32:71-80. DOI: 10.4028/www.scientific.net/ JNanoR.32.71

Oberdörster G, Sharp Z, Atudorei V, Elder A, Gelein R, Kreyling W, Cox C. Translocation of inhaled ultrafine particles to the brain. Inhal Toxicol. 2004;16:437-45. PMID: 15204759 DOI: $10.1080 / 08958370490439597$

Palombo M, Deshmukh M, Myers D, Gao J, Szekely Z, Sinko PJ. Pharmaceutical and toxicological properties of engineered nanomaterials for drug delivery. Annu Rev Pharmacol Toxicol. 2014;54:581-98. PMID: 24160695 DOI: 10.1146/annurev-pharmtox-010611-134615

Rollerova E, Jurcovicova J, Mlynarcikova A, Sadlonova I, Bilanicova D, Wsolova L, Kiss A, Kovriznych J, Kronek J, Ciampor F, Vavra I, Scsukova S. Delayed adverse effects of neonatal exposure to polymeric nanoparticle poly(ethylene glycol)-block-polylactide methyl ether on hypothalamic-pituitary-ovarian axis development and function in Wistar rats. Reprod Toxicol. 2015;57:165-75. PMID: 26193689 DOI: $10.1016 /$ j.reprotox.2015.07.072
Sharifi S, Behzadi S, Laurent S, Forrest $M L$, Stroeve $\mathrm{P}_{\text {, }}$ Mahmoudi M. Toxicity of nanomaterials. Chem Soc Rev. 2012;41:2323-43. PMID: 22170510 DOI: 10.1039/ C1CS15188F

Scsukova S, Mlynarcikova A, Kiss A, Rollerova E. Effect of polymeric nanoparticle poly(ethylene glycol)-block-poly(lactic acid) (PEG-b-PLA) on in vitro luteinizing hormone release from anterior pituitary cells of infantile and adult female rats. Neuro Endocrinol Lett. 2015;36:88-94. PMID: 26757115

Soleymani S, Zare-Zardini H, Azam AG, Hashemi A, Ebrahimi L, Esfahanian Z, Zolfaghari F. A Review of Toxicity of Some Conventional Nanomaterials. J Pharm Health Sci. 2014;2:109-14.

Tseng JM, Kuo CY, Liu MY, Shu CM. Emergency response plan for boiler explosion with toxicchemical releases at NanKung industrial park in central Taiwan. Process Saf Environ Prot. 2008;86:415-20. DOI: 10.1016/j.psep.2008.05.004

Yang H, Du L, Wu G, Wu Z, Keelan JA. Murine exposure to gold nanoparticles during early pregnancy promotes abortion by inhibiting ectodermal differentiation. Mol Med. 2018;24:62. PMID: 30509178 DOI: 10.1186/s10020-018-0061-2

Zardini HZ, Amiri A, Shanbedi M, Maghrebi M, Baniadam $M$. Enhanced antibacterial activity of amino acids-functionalized multi walled carbon nanotubes by a simple method. Colloids Surf B Biointerfaces. 2012;92:196-202. PMID: 22197225 DOI: 10.1016/j.colsurfb.2011.11.045

Zardini HZ, Davarpanah M, Shanbedi M, Amiri A, Maghrebi M, Ebrahimi L. Microbial toxicity of ethanolamines--multiwalled carbon nanotubes. J Biomed Mater Res A. 2014;102:177481. PMID: 23784887 DOI: 10.1002/jbm.a.34846

Zare-Zardini H, Amiri A, Shanbedi M, Taheri-Kafrani A, Kazi $\mathrm{SN}$, Chew BT, Razmjou A. In vitro and in vivo study of hazardous effects of $\mathrm{Ag}$ nanoparticles and Arginine-treated multi walled carbon nanotubes on blood cells: application in hemodialysis membranes. J Biomed Mater Res A. 2015a;103:2959-65. DOI: 10.1002/jbm.a.35425

Zare-Zardini H, Amiri A, Shanbedi M, Taheri-Kafrani A, Sadri $Z$, Ghanizadeh $F$, Neamatzadeh $H$, Sheikhpour R, Keyvani Boroujeni F, Masoumi Dehshiri R, Hashemi A, Aminorroaya MM, Dehgahnzadeh MR, Shahriari Sh. Nanotechnology and Pediatric Cancer: Prevention, Diagnosis and Treatment. Iran J Ped Hematol Oncol. 2015b;5:233-48.

Zhang $M$, Jin J, Chang YN, Chang X, Xing G. Toxicological properties of nanomaterials. J Nanosci Nanotechnol. 2014;14:717-29. PMID: 24730292 DOI: 10.1166/ jnn.2014.9198

Zhao J, Castranova V. Toxicology of nanomaterials used in nanomedicine. J Toxicol Environ Health B Crit Rev. 2011;14:593-632. PMID: 22008094 DOI: $10.1080 / 10937404.2011 .615113$ 